\title{
Transcervical resection of endometrium as a conservative management of dysfunctional uterine bleeding in premenopausal patients
}

\author{
Girish A. Pote, Namita N. Raut*
}

Department of Obstetrics and Gynecology, B. J. Medical College and Sassoon Hospital, Pune, Maharashtra, India

Received: 18 September 2019

Accepted: 05 October 2019

\section{*Correspondence:}

Dr. Namita N. Raut,

E-mail: namitaraut87@gmail.com

Copyright: (C) the author(s), publisher and licensee Medip Academy. This is an open-access article distributed under the terms of the Creative Commons Attribution Non-Commercial License, which permits unrestricted non-commercial use, distribution, and reproduction in any medium, provided the original work is properly cited.

\begin{abstract}
Background: Dysfunctional uterine bleeding (DUB) affects $10 \%$ to $15 \%$ women of reproductive age group. A prospective observational study was performed to study the efficacy, rate of satisfaction and adverse effects of Transcervical resection of endometrium (TCRE) in the treatment of DUB in premenopausal women.

Methods: 30 patients with DUB attending the hospital underwent TCRE and patients were followed up after 6 week, 3 months, 6 months up to 1 year and there bleeding score was calculated. Their response to treatment, complications and satisfaction rate were studied.

Results: $43.3 \%$ of the women in this study were in the age group of $40-44$ years. Post TCRE, $43.33 \%(n=13)$ had hypomenorrhea. $33.33 \%(n=10)$ had regular cycle, $13.33 \%(n=4)$ women had amenorrhea and $10 \%(n=3)$ had no response and underwent hysterectomy. $86.66 \%(\mathrm{n}=26)$ women were satisfied with the treatment whereas $13.33 \%$ $(n=4)$ were not satisfied. One patient had uterine perforation and serosal bowel injury due to extended cautery injury. Bleeding reduced considerably and a statistically significant (paired t-test, p-value $<0.05$ ) difference was observed in pre and post procedure (6 weeks, 3 months, 6 months and 1 year) bleeding scores.

Conclusions: Considering advantages like shorter operative time, uterine conservation and early mobility TCRE is a procedure of choice in patients in whom hysterectomy is either technically difficult or medically contraindicated or in those who are not suitable for long term medical management.
\end{abstract}

Keywords: Ablation, Dysfunctional uterine bleeding, Menorrhagia, Transcervical resection of endometrium

\section{INTRODUCTION}

Dysfunctional Uterine Bleeding constitutes a considerable problem for about $10 \%$ to $15 \%$ women of reproductive age group causing discomfort, anxiety and decreased quality of life. ${ }^{1}$ Hysteroscopic surgery in the form of endometrial ablation is an advanced and less invasive technique, which is true alternative to hysterectomy, in the management of DUB especially in younger women. It enables patients to resume their routine daily activities within short period of time and is particularly useful in those not responding to medical management and those who are at high risk for undergoing major surgery. Transcervical resection of endometrium (T.C.R.E.) is a first generation hysteroscopic endometrial ablation technique that has gained popularity in gynaecological practice as an alternative to hysterectomy for patients presenting with dysfunctional uterine bleeding. The results so far suggest that T.C.R.E. is of comparable efficacy in producing hypomenorrhea in $80 \%$ to $90 \%$ and amenorrhoea in $25 \%$ to $50 \% .^{2-5}$ 


\section{METHODS}

The sample size for the study was 30 patients which were maximum number of cases of DUB in eighteen months who underwent TCRE. All patients with DUB attending Gynaecology outpatient Department at Sassoon General Hospital over the period of eighteen months from December 2013 to June 2015, who fulfilled the inclusion criteria were included in the study.

\section{Inclusion criteria}

- $\quad$ Failed medical management

- Medical management was contraindicated or had adverse effects of it. (previous history of deep venous thrombosis, thromboembolism, liver disease)

- Cases who are unfit for hysterectomy

- Cases not willing for hysterectomy.

\section{Exclusion criteria}

- Women who want to retain fertility

- Acute genital tract infections

- Adenomyosis

- Uterine size greater than 12 weeks/ cavity greater than $12 \mathrm{~cm}$

- Abnormal endometrial and cervical cytology.

\section{Preoperative preparation}

Written and informed consent was obtained after explaining all other presently available treatment modalities. All women were told about the possibility of laparotomy and any other surgical procedure if clinically indicated at the time of surgery. All routine investigations were done including endometrial biopsy to rule out dysplasia or malignancy, Pap smear for cervical cytology, transvaginal sonography for endometrial thickness and size of uterus. Blood transfusion was given in patients in whom haemoglobin levels was less than $10 \mathrm{gm} \%$. In this study routine preoperative preparation of the endometrium with hormones was not done. In all patient's surgery was performed immediately post menstrually when endometrial thickness is at its minimum. All procedures were performed under spinal anaesthesia.

\section{Procedure}

The bladder was emptied. Cervix was dilated up to Hegar 10 and then the resectoscope was introduced. The uterus was distended with the help of $1.5 \%$ glycine. The cuff of the pneumatic tourniquet was wrapped around the plastic bottle and pressure was raised to $100 \mathrm{mmHg}$ to maintain a steady intrauterine pressure. A pure cutting current (100 watts) was used to resect the endometrium using a cutting loop electrode. The procedure was started at the fundus and then the endometrium from anterior, posterior and lateral walls was systematically shaved up to basal layer. Special care was taken in the lateral walls especially near the isthmus where deep cuts were avoided to prevent injury to the branches of uterine vessels. During the entire procedure patient was closely observed for evidence of fluid overload and abdominal distension. Most of the endometrial debris were removed at the end of surgery and sent for histopathological examination.

\section{Follow up}

Cases were reviewed in OPD after 6 weeks, 3 and 6 months and 1 year. All patients were asked to keep a menstrual record which included interval of cycle, days of bleeding, number of pads soaked and Bleeding score. Depending upon the parameters like return to normal domestic activity, continued bleeding, adverse effects like abdominal pain, per vaginal discharge patient's satisfaction was assessed. Blood loss was assessed by Pictorial Blood Loss Assessment Chart.

\section{Statistical analysis}

Statistical analysis was done using SPSS software version18. Paired T-test was used to compare mean bleeding score.

\section{RESULTS}

Majority of the women in this study were in the age group of 40-44 years (43.3\%). $40 \%$ were in age group of 35-39 years and $16 \%$ in age group of 30-34 years (Figure 1).

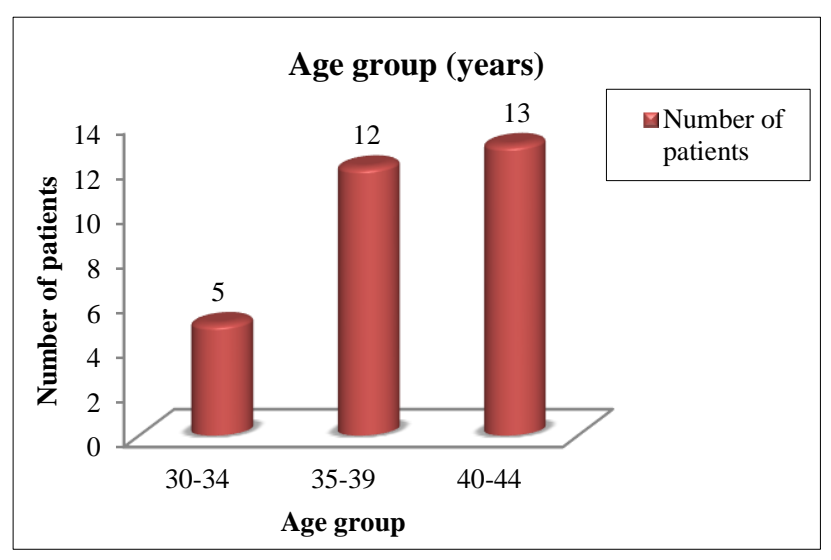

Figure 1: Age wise distribution of cases.

Table 1: Distribution of women with respect to parity.

\begin{tabular}{|lll|}
\hline Parity & No. of patients & $(\%)$ \\
\hline 1 & 1 & 3.3 \\
\hline 2 & 13 & 43.3 \\
\hline 3 & 15 & 50.0 \\
\hline 4 & 1 & 3.4 \\
\hline Total & $\mathbf{3 0}$ & $\mathbf{1 0 0 . 0}$ \\
\hline
\end{tabular}

The $97.7 \%$ were multiparous and one (3.3\%) was primiparous (Table 1). All women had their family 
completed. Five women $(16.67 \%)$ had history of taking Progesterone for about 6 months and Twenty-five $(83.33 \%)$ took Mefenamic acid, Tranexamic acid as medical management (Table 2).

Table 2: Prior treatment taken.

\begin{tabular}{|llll|}
\hline \multirow{2}{*}{ Medical } & $\begin{array}{l}\text { Treatment } \\
\text { taken }\end{array}$ & $\begin{array}{l}\text { No. of } \\
\text { patients }\end{array}$ & $\begin{array}{l}\text { Percentage } \\
(\%)\end{array}$ \\
\cline { 2 - 4 } & Hormonal & 5 & 16.67 \\
\cline { 2 - 4 } & NSAID & 25 & 83.33 \\
\hline & Total & $\mathbf{3 0}$ & $\mathbf{1 0 0 \%}$ \\
\hline
\end{tabular}

Six (20\%) were previous LSCS. Two (6.67\%) were known case of hypertension. Five women had BMI $>30$. Three (10\%) women had anemia Haemoglobin <10 gm\% (Table 3).

Table 3: Distribution of women with high risk factors.

\begin{tabular}{|lll|}
\hline Risk factor & No. of patients & Percentage (\%) \\
\hline Anemia & 3 & 10.0 \\
\hline Hypertension & 2 & 6.67 \\
\hline Obesity & 5 & 16.67 \\
\hline Previous LSCS & 6 & 20.0 \\
\hline
\end{tabular}

All women underwent Diagnostic curettage before the procedure. After D and C 40\% ie. Twelve had secretory endometrium and $60 \%$ ie. Eighteen women had proliferative endometrium (Table 4).

Table 4: Preoperative histopathological findings.

\begin{tabular}{|lll|}
\hline Histopathology & No. of patients & Percentage (\%) \\
\hline Proliferative & 18 & 60.0 \\
\hline Secretory & 12 & 40.0 \\
\hline Total & $\mathbf{3 0}$ & $\mathbf{1 0 0 . 0}$ \\
\hline
\end{tabular}

Twenty-nine -patients were discharge after 48 hours and one patient with uterine perforation was kept for 7 days (Table 5).

Table 5: Days of hospital stay.

\begin{tabular}{|lll|}
\hline Hospital stay (days) & No. of patients & $(\%)$ \\
\hline$<2$ day & 29 & 96.67 \\
\hline$>2$ day & 01 & 3.33 \\
\hline Total & $\mathbf{3 0}$ & $\mathbf{1 0 0 . 0}$ \\
\hline
\end{tabular}

Table 6: Postoperative histopathological findings.

\begin{tabular}{|lll|}
\hline $\begin{array}{l}\text { Post-operative } \\
\text { histopathological findings }\end{array}$ & $\begin{array}{l}\text { No. of } \\
\text { patients }\end{array}$ & $\begin{array}{l}\text { Percentage } \\
(\%)\end{array}$ \\
\hline Proliferative & 0 & 0 \\
\hline Secretory & 27 & 90 \\
\hline Simple cystic hyperplasia & 1 & 3.33 \\
\hline Adenomatous hyperplasia & 2 & 6.66 \\
\hline
\end{tabular}

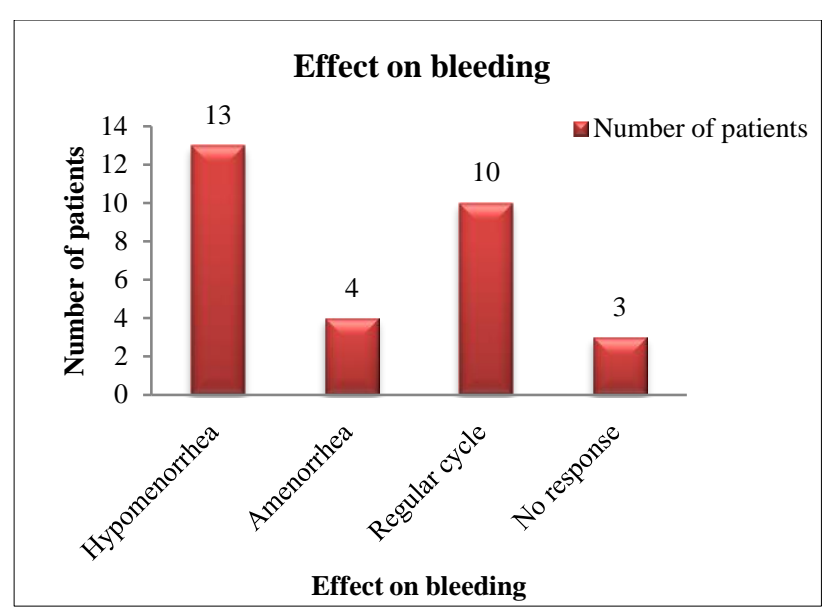

Figure 2: Effect on bleeding.

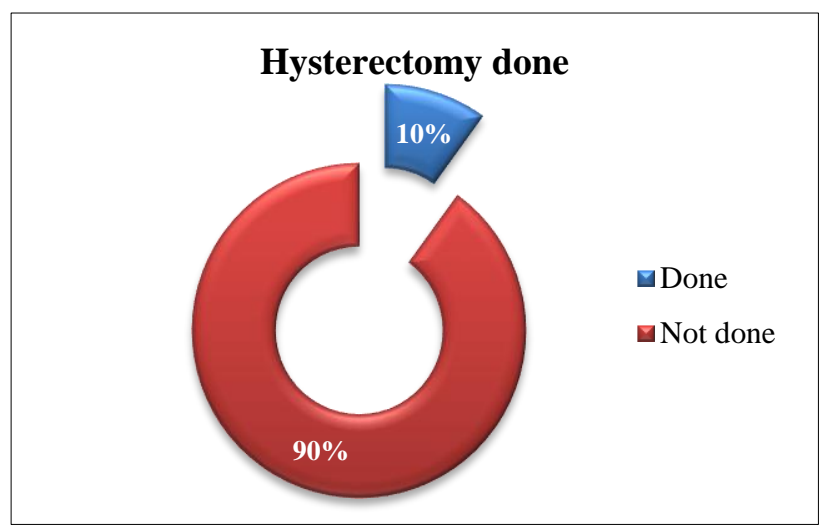

Figure 3: Hysterectomy required.

Twenty-seven women had secretory endometrium. One had simple cystic hyperplasia and two had adenomatous hyperplasia (Table 6). Post TCRE (43.33\%) thirteen had hypomenorrhea. $(33.33 \%)$ ten had regular cycle. Four $(13.33 \%)$ women had amenorrhea and three (10\%) had no response ie they underwent hysterectomy (Figure 2, $3)$. $(86.66 \%)$ twenty-six women were satisfied with the treatment whereas $(13.33 \%)$ four were not satisfied (Table 7).

Table 7: Patients satisfaction.

\begin{tabular}{|lll|}
\hline Patient satisfaction & No. of patients & Percentage (\%) \\
\hline Satisfied & 26 & 86.66 \\
\hline Not satisfied & 4 & 13.33 \\
\hline Total & $\mathbf{3 0}$ & $\mathbf{1 0 0}$ \\
\hline
\end{tabular}

One patient had uterine perforation and same patient had serosal bowel injury due to extended cautery injury (Table 8). No postoperative complications were noted. By using paired t-test $\mathrm{p}$-value was $<0.05$ therefore there was significant difference between mean bleeding score before the procedure and after procedure at 6 weeks, 3 months, 6 months and 1 year (Table 9). Thus, bleeding reduced considerably after TCRE procedure (Figure 4). 
Table 8: Intraoperative complications.

\begin{tabular}{|lll|}
\hline $\begin{array}{l}\text { Intra operative } \\
\text { complication }\end{array}$ & $\begin{array}{l}\text { No. of } \\
\text { patients }\end{array}$ & $\begin{array}{l}\text { Percentage } \\
(\%)\end{array}$ \\
\hline Uterine perforation & 1 & 3.33 \\
\hline Bowel injury & 1 & 3.33 \\
\hline
\end{tabular}

Table 9: Comparison of mean bleeding score at before procedure, after procedure at 6 weeks, 3 months 6 months and 1 year.

\begin{tabular}{|lllll|}
\hline & $\begin{array}{l}\text { Number of } \\
\text { patients }\end{array}$ & \multicolumn{2}{c|}{ Bleeding score } & P- \\
Mean & SD & value \\
\hline $\begin{array}{l}\text { Before } \\
\text { procedure }\end{array}$ & 30 & 115.67 & 9.93 & \\
\hline 6 weeks & 30 & 45.6 & 45.6 & $<0.001$ \\
\hline 3 months & 30 & 33.43 & 33.21 & $<0.001$ \\
\hline 6 months & 30 & 29.57 & 31.85 & $<0.001$ \\
\hline 1 year & 30 & 17.67 & 10.56 & $<0.001$ \\
\hline
\end{tabular}

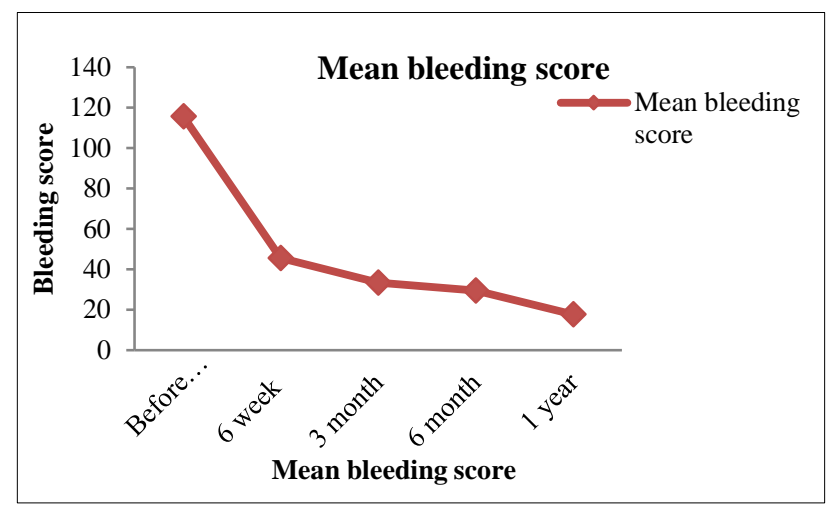

Figure 4: Mean bleeding score.

\section{DISCUSSION}

The concept of endometrial destruction by various methods is not new. However, the introduction of operating hysteroscope with technical advances in optics, illumination, electrocautery and availability of safe distension media has now allowed the endometrium to be destroyed under direct vision. Visual inspection assures the operator of completeness of the intervention. The objective of the intervention is to cause thermal damage to the entire endometrium deep enough to destroy the basal layer. Comparison of intraoperative complications in various studies showed uterine perforation was observed in $1 \%$ cases in Maltau $\mathrm{JM}$ et al, and $3.2 \%$ in Pooley AS et al, whereas fluid overload was seen in $0.8 \%$ cases in Maltau JM et al and $0.9 \%$ in Pooley AS et al, study. Postoperative complications like pyrexia was in $0.8 \%$ and secondary haemorrhage $2 \%$ in Agbolla AJ et al, study and haematometra in $1.7 \%$ in Chandel NP et al, study. $2,4,6,8$

Advantages of TCRE over other second-generation ablation techniques include

- Tissue can be obtained for histopathological diagnosis

- Direct visualization of uterine cavity is possible

- Cochrane systemic review 2009 review revealed that equipment failure, nausea, vomiting and uterine cramping were more common with second generation devices

- Microwave and thermal ablation are contraindicated in previous classical scar or previous surgery or trauma leading to uterine wall thickness of less than $8 \mathrm{~mm} .{ }^{9}$

Table 10: Comparison of intraoperative complications of various studies.

\begin{tabular}{|lllllll|}
\hline $\begin{array}{l}\text { Complications } \\
\text { Bowel injury }\end{array}$ & $\begin{array}{l}\text { Maltau JM } \\
\text { et al }\end{array}$ & $\begin{array}{l}\text { Pooley AS } \\
\text { et al }\end{array}$ & $\begin{array}{l}\text { Agbolla AJ } \\
\text { et al }\end{array}$ & $\begin{array}{l}\text { Engelson B } \\
\text { et al }^{3}\end{array}$ & $\begin{array}{l}\text { Chandel NP } \\
\text { et al }^{8}\end{array}$ & $\begin{array}{l}\text { Present } \\
\text { study }^{8}\end{array}$ \\
\hline Uterine perforation & $1 \%$ & - & - & - & - & $3.33 \%$ \\
\hline Fluid overload & $0.8 \%$ & $0.9 \%$ & - & - & - & $3.33 \%$ \\
\hline Haemorrhage & - & - & $3.5 \%$ & - & - & - \\
\hline
\end{tabular}

Table 11: Comparison of postoperative complications of various studies.

\begin{tabular}{|lllllll|}
\hline Complications & $\begin{array}{l}\text { Maltau JM } \\
\text { et al }\end{array}$ & $\begin{array}{l}\text { Pooley AS } \\
\text { et al }\end{array}$ & $\begin{array}{l}\text { Agbolla AJ } \\
\text { et al }\end{array}$ & $\begin{array}{l}\text { Engelson B } \\
\text { et al }^{3}\end{array}$ & $\begin{array}{l}\text { Chandel NP } \\
\text { et al }^{8}\end{array}$ & $\begin{array}{l}\text { Present } \\
\text { study }^{7}\end{array}$ \\
\hline Pyrexia & - & - & O.8\% & - & - & - \\
\hline Pelvic infection & - & - & - & $0.6 \%$ & - & - \\
\hline Haematometra & - & - & - & - & $1.7 \%$ & - \\
\hline Secondary haemorrhage & - & - & $2 \%$ & -- & & - \\
\hline
\end{tabular}

After comparing all available treatment modalities, transcervical resection of endometrium has been proved to be, feasible, cost effective with shorter duration of hospital stay and faster recovery for dysfunctional uterine bleeding as compared to hysterectomy. ${ }^{10}$ Sculpher MJ et al, in his study has found that the total mean cost of 
surgically treating menorrhagia using endometrial resection is significantly lower than that using abdominal hysterectomy. The mean total cost of resection was 53\% that of hysterectomy. ${ }^{11}$

\section{CONCLUSION}

Considering advantages like shorter operative time, uterine conservation and early mobility TCRE is a procedure of choice in patients in whom hysterectomy is either technically difficult or medically contraindicated or in those who are not suitable for long term medical management.

\section{Funding: No funding sources}

Conflict of interest: None declared

Ethical approval: The study was approved by the Institutional Ethics Committee

\section{REFERENCES}

1. Frick KD, Clark MA, Steinwachs DM. Financial and quality-of-life burden of dysfunctional uterine bleeding among women agreeing to obtain surgical treatment. Womens Health Issues. 2009;19(1):70-3.

2. Agboola AJ, Kulatilake K, Jayawickrama NS. Posttreatment hypomenorrhoea- a clinical indicator of longterm successful outcome of transcervical resection of the endometrium. J Obstet Gynaecol. 2004;24(4):446-7.

3. Bøe Engelsen I, Woie K, Hordnes K. Transcervical endometrial resection: long-term results of 390 procedures. Acta Obstet Gynecol Scand. 2006;85(1):82-7.

4. Cooper KG, Jack SA, Parkin DE, Grant AM. Fiveyear follow up of women randomised to medical management or transcervical resection of the endometrium for heavy menstrual loss: Clinical and quality of life outcomes. Br J Obstet Gynaecol. 2001;108(12):1222-8.
5. Duan H, Xia E, Yu D, Zhao Y, Zheng J, Cheng J, et al. Analysis of the efficiency of transcervical resection of endometrium for treating dysfunctional uterine bleeding and factors reducing the efficiency of the operation. Zhonghua Fu Chan Ke Za Zhi. 2004;39(5):301-4.

6. Maltau JM, Meyer L, Bakke K. Transcervical resection of the endometrium. An alternative to hysterectomy in dysfunctional uterine hemorrhage. Am J Obstet Gynaecol. 1994;114(15):1691-3.

7. Pooley AS, Ewen SP, Sutton CJ. Does transcervical resection of the endometrium for menorrhagia really avoid hysterectomy? Life table analysis of a large series. J Am Asso Gynecol Laparo. 1998;5(3):22935

8. Chandel NP. Treatment analysis of transcervical resection of endometrium (TCRE) in heavy menstrual bleeding. Indian J Obstet Gynaecol. 2015;2(1):28-35.

9. Lethaby A, Hickey M, Garry R. Endometrial destruction techniques for heavy menstrual bleeding. Cochrane Database Syst Rev. 2009(4);CD001501.

10. Lethaby A, Shepperd S, Cook I. Endometrial resection and ablation versus hysterectomy for heavy menstrual bleeding. Cochrane Database Syst Rev. 2000;(2):CD000329.

11. Sculpher MJ, Bryan S, Dwyer N. An economic evaluation of transcervical endometrial resection versus abdominal hysterectomy for the treatment of menorrhagia. Br J Obstet Gynaecol. 1993;100:24452.

Cite this article as: Pote GA, Raut NN.

Transcervical resection of endometrium as a conservative management of dysfunctional uterine bleeding in premenopausal patients. Int J Reprod Contracept Obstet Gynecol 2019;8:4208-12. 